\title{
Influence of Prestress Environment on Annual Bluegrass Heat Tolerance ${ }^{1}$
}

\author{
D. L. Martin and D. J. Wehner ${ }^{2}$
}

\begin{abstract}
Annual bluegrass (Poa annua L.) turf quality is reduced during periods of high temperature. To predict heat stress injury and develop improved prestress maintenance practices, an understanding of the seasonal variation in annual bluegrass heat tolerance and the influence of soil moisture on heat tolerance is crucial. Annual bluegrass growing in the field on a Drummer silty clay loam (fine silty, mixed, mesic Typic Haplaquolls) was sampled on 23 dates over two growing seasons and brought to a laboratory for exposure to high temperature. Prestress environmental conditions (air and soil temperature, soil matric potential, plant water potential, daylength, rainfall and irrigation) were monitored. Plants were enclosed in plastic bags, exposed for $30 \mathrm{~min}$ to temperatures in the range 40 to $48^{\circ} \mathrm{C}$ in a water bath and placed in a greenhouse for a 2-week recovery period. The dry weight of the stressed plants expressed as a percentage of the controls (heat tolerance indices, HTI) was used as a measure of heat tolerance. In a second experiment, field plots of annual bluegrass were maintained for one growing season under either a dry (rainfall plus irrigation to prevent severe wilting) or moist (dry treatment plus $10-\mathrm{mm}$ irrigation every other day) soil regime. Plants were stress-tested on five dates when differences in soil matric potentials existed between treatments, and on five dates when matric potentials were identical (saturated soil). Turfgrass color, quality, and rooting depth were monitored. The best equation fitted to HTI using the results of the first experiment was: $y=15.6 \times A+9.85$ $\times B-0.22 \times A^{2}-0.31 \times B^{2}-0.25 \times A \times B-194.71\left(R^{2}\right.$ $=0.78, p=0.0001$, where $A=$ mean maximum daily air temperature $\left({ }^{\circ} \mathrm{C}\right)$ for the 2 days preceding sampling and $B=$ mean total precipitation ( $\mathrm{mm}$ ) of the period 2 through 4 days prior to sampling. The second experiment revealed a nonsignificant trend for annual bluegrass maintained under moist soil conditions to be less heat tolerant than that under dry conditions. No differences were found due to treatment in rooting depth which negatively correlated $(r=$ -0.83 ) with the soil temperature at $10 \mathrm{~cm}$. Because of reduced turfgrass quality with the dry soil conditions, there appeared to be little potential for increasing heat tolerance through irrigation management.
\end{abstract}

Additional index words: Poa annua L., Heat stress, Irrigation, Drought stress, Heat stress injury, High temperature stress.
A NNUal bluegrass ( Poa annua L.), a component $A$ of many high maintenance temperate zone turfs, often has reduced quality during periods of high temperature. Research to improve summer quality of turfgrasses has involved evaluating the heat tolerance of species or cultivars and investigating cultural practices that may promote stress tolerance. In the case of the unintentionally introduced species of annual bluegrass, the major strategy for improving summer performance has been the utilization of management practices to improve stress tolerance. Although considerable intraspecific variability exists in the high temperature response of annual bluegrass (Calder, 1973; Cordukes, 1977; Duff, 1978), the variability does not appear to be predictable on the basis of collection site data such as latitude or long-term mean July temperature (Martin, 1986).

Of the factors known to influence heat tolerance, the turfgrass manager has control over cultural practices such as irrigation, fertilization, and mowing. Julander (1945) examined the effect of clipping frequency and watering practices on the heat tolerance of several grasses. He reported that under frequent watering, all species were heat sensitive; under infrequent irrigation, species differences were manifested. Clipping frequency had little effect on heat tolerance. Wallner et al. (1982) used electrolyte leakage from leaf segments heated at $48^{\circ} \mathrm{C}$ for $30 \mathrm{~min}$ as a measure of heat tolerance of turfgrasses exposed to water stress pretreat-

\footnotetext{
' Contribution from the Horticulture Dep., Univ. of Illinois. This study was part of project no. 65-356 of the Agric. Exp. Stn., Univ. of IIlinois, Urbana, IL 61801. Received 11 Aug. 1986.

${ }^{2}$ Graduate research assistant and associate professor, respectively, Horticulture Dep., Univ. of Illinois, Urbana, IL 61801 .
}

Published in Crop Sci. 27:579-585 (1987). 
ments. Drought stress was imposed by (i) reducing the quantity of water given to plants, (ii) watering with a -1.2-MPa solution of polyethylene glycol (PEG), or (iii) floating tissue in a - 1.2-MPa PEG solution immediately prior to heat stress imposition. Contrary to the finding of Julander (1945) and the suggestion of Levitt (1980) that most plants are less heat tolerant when plant water content is high, Wallner et al. (1982) found no differences in heat tolerance between drought stressed and nonstressed tissue.

Work by Minner et al. (1983) and Wehner et al. (1985) with field-grown Kentucky bluegrass (Poa pratensis $\mathrm{L}$.) showed that moderate quantities of $\mathrm{N}(0,98$, 148 , and $196 \mathrm{~kg} \mathrm{~N} \mathrm{ha}^{-1} \mathrm{yr}^{-1}$ ), with one-half or more of the $\mathrm{N}$ applied in the fall, had no effect on the heat tolerance of the plants.

The influence of maintenance level on heat tolerance of cool season grasses has been studied by Wehner and Watschke (1981) using growth chamber-grown plants. They maintained annual bluegrass and four Kentucky bluegrasses under low maintenance (a single application of $11.8 \mathrm{~kg} \mathrm{~N} \mathrm{ha}^{-1}$, soil moisture allowed to dry to $110 \mathrm{~g} \mathrm{~kg}^{-1}$ before replenishing to $260 \mathrm{~g} \mathrm{~kg}^{-1}$, and high maintenance (four weekly applications of 23.6 $\mathrm{kg} \mathrm{N} \mathrm{ha-1,} \mathrm{soil} \mathrm{moisture} \mathrm{maintained} \mathrm{at} 260 \mathrm{~g} \mathrm{~kg}^{-1}$ ) conditions for a 4-week period prior to heat stress imposition. They found that the plants under the low maintenance regime were more heat tolerant than those under the high maintenance regime. Annual bluegrass was less heat tolerant than the Kentucky bluegrass cultivars under low maintenance; however, under high maintenance, there was no difference in heat tolerance.

Wehner et al. (1985) developed a regression equation relating the recovery weight of field-grown Kentucky bluegrass subjected to heat stress with environmental conditions prior to heat stress testing. The mean low temperature for the 2 days prior to sampling and daylength of the sampling date were factors in the bestfit equation. Although Wehner et al. (1985) reported that the average high temperature and the amount of rainfall preceding the dates of heat tolerance screening did not correlate with recovery weight $(r=0.10$ and $r=-0.33$ ), Minner et al. (1983) found a high degree of correlation between the recovery weight and these two environmental parameters $(r=0.93$ and $r=$ $-0.91)$. This discrepancy may have been due to the fact that Wehner et al. (1985) sampled for heat tolerance from May through October while Minner et al. (1983) sampled only during June, July, and August. In Maryland, where both studies were conducted, October high temperatures can often reach $27^{\circ} \mathrm{C}$, but they occur in conjunction with cool nights and last only a few hours during the day. During summer, tempera. tures of $27^{\circ} \mathrm{C}$ are of longer duration and are coupled with warmer night temperatures. Wehner et al. (1985) pointed out the need for determining (i) the importance of plant water status, and (ii) the minimum amount of time needed for conditioning of heat tolerance in order to develop better models for predicting turfgrass heat tolerance.

The objectives of our research were to monitor the heat tolerance of field grown annual bluegrass over the growing season, and to examine the effect of two different soil moisture regimes on heat tolerance, color, quality, and rooting depth.

\section{MATERIALS AND METHODS \\ Heat Tolerance Monitoring Study}

An annual bluegrass stand was established in August 1983 at the Ornamental Horticulture Research Center, Urbana, IL on a Drummer silty clay loam (fine silty, mixed, mesic Typic Haplaquolls) with a $\mathrm{pH}$ of 6.7. Germination of annual bluegrass seed present in the soil was stimulated by frequent irrigation of the site; other species present were removed from the area by spot spraying with glyphosate $[N$-(phosphonomethyl)glycine]. The area was fertilized with $49 \mathrm{~kg} \mathrm{~N}$, $4.4 \mathrm{~kg} \mathrm{P}$, and $20.4 \mathrm{~kg} \mathrm{~K} \mathrm{ha}^{-1}$ at the time of establishment, and thereafter maintained by fertilization at the rate of 196 $\mathrm{kg} \mathrm{N}, 17.6 \mathrm{~kg} \mathrm{P}$, and $81.6 \mathrm{~kg} \mathrm{~K} \mathrm{ha-1} \mathrm{yr}^{-1}$ from an 18-1.67.5 source. The stand was mowed to a $2.5 \mathrm{~cm}$ height, and irrigated as needed to prevent severe wilting.

In May of $1984,36 \mathrm{~m}^{2}$ of annual bluegrass turf was blocked into four 3- by 3-m plots for heat tolerance monitoring. Plant samples were removed from the stand on 23 sampling dates over the 1984 and 1985 growing seasons and evaluated for heat tolerance. The procedure used for stress testing was described by Minner et al. (1983). Briefly, it involved placing plants in plastic bags and immersing them in a water bath for $30 \mathrm{~min}$ at each temperature in one-degree intervals in the range of 40 to $48^{\circ} \mathrm{C}$ and then replanting them in a greenhouse. Four replications (10 plants per replicate) were heated at each temperature. A heat tolerance index (HTI) was calculated for each replicate by expressing the dry weight of the treated plants as a percentage of the mean dry weight of two sets of controls. Heat tolerance indices from plants treated at $40,42,43,44$, and $45^{\circ} \mathrm{C}$ were averaged to give an overall index for each sampling date. These indices were used because they gave the best correlation with environmental parameters.

Heat tolerance indices from all 23 sampling dates were analyzed using multiple regression procedures (SAS Inst., 1982) to relate HTI to environmental parameters associated with each sampling date. The following parameters were tested: maximum and minimum air and soil temperatures, soil matric potential, and total precipitation (irrigation + rainfall) for various time periods ranging from 2 weeks to 1 day before stress exposure, plant water potential immediately prior to stress exposure, and daylength at sampling. Air temperature and soil temperature at $10 \mathrm{~cm}$ under turf were obtained from a standard weather station located within 1 $\mathrm{km}$ of the annual bluegrass stand. Total precipitation was measured on site. Soil matric potentials were measured using tensiometers at the $5-\mathrm{cm}$ depth (on site) between 0900 and $1000 \mathrm{~h}$. Plant water potential readings were taken from plants using the Scholander pressure bomb technique (Boyer, 1967), in the minutes immediately preceding imposition of heat stress. Annual bluegrass plants were stripped of their root systems and placed between moist paper towels before being sealed in a plastic bag for transportation to the laboratory where plant water potentials were immediately determined. The rate of pressurization of the bomb was $54.5 \mathrm{kPa} \mathrm{s}^{-1}$.

Soil cores $20 \mathrm{~cm}$ deep by $2.5 \mathrm{~cm}$ in diameter were removed from each of the plots on 10 sampling dates in 1985. The cores were soaked overnight in water to facilitate the removal of soil from the roots. The maximum length (depth) of the root system was then recorded for each profile.

\section{Water Study}

Six 1.2- by $2.4-\mathrm{m}$ plots (two treatments $\times$ three replications) were used in a randomized complete block design on an adjacent portion of the annual bluegrass stand. To prevent lateral movement of water between plots, $3.2-\mathrm{mm}$ thick 
Table 1. Soil matric potential for sampling dates when a difference existed between wet and dry treatments. Each reading is the mean of three replications.

\begin{tabular}{lcc}
\hline & \multicolumn{2}{c}{ Tensiometer reading } \\
\cline { 2 - 3 } Sampling date 1985 & Wet treatment & Dry treatment \\
\cline { 2 - 3 } 30 May & & \\
20 June & 7.0 & 34.3 \\
19 July & 7.7 & 35.7 \\
19 August & 12.3 & 31.7 \\
28 August & 0.0 & 14.0 \\
\hline
\end{tabular}

Fe plate was driven to a depth of $15.2 \mathrm{~cm}$ with approximately $6 \mathrm{~mm}$ of plate above the thatch layer. Tensiometers were inserted horizontally into the plots through holes cut in the Fe plate at the 5 -cm depth.

Two different moisture maintenance practices began on 19 May 1985. Annual bluegrass maintained under a "dry treatment" received rainfall plus enough irrigation to prevent severe wilting. Annual bluegrass maintained under a "wet treatment" received $10 \mathrm{~mm}$ of irrigation approximately every other day in addition to rainfall and any irrigation applied to the dry treatment. The only dates on which the $10-\mathrm{mm}$ watering treatment was not applied to the wet treatment were days when irrigation of the dry area or when rainfall exceeded $10 \mathrm{~mm}$.

The annual bluegrass maintained under the two moisture regimes was evaluated for heat tolerance on 10 dates during 1985. Heat tolerance testing was performed on five dates when differences in soil matric potential existed between the treated plots (Table 1; 30 May, 20 June, 19 July, 19 August, and 28 August) and on five dates when the soil matric potentials of plots were the same (soil for both treatments at saturation: 31 May, 21 June, 20 August, and 29 August). Soil matric potentials were the same on dates following either heavy rains or irrigation that saturated the soil to the $5-\mathrm{cm}$ depth. The procedure for imposing heat stress was the same as that previously discussed.

The HTI of plants exposed to 43,44 , and $45^{\circ} \mathrm{C}$, the linear portion of the sigmoidal $\mathrm{HTI} /$ temperature response curve, were used in the analysis of variance (ANOVA) procedures. The HTI were analyzed as a split-split plot in time, with watering treatments as whole plots, sampling dates as subplots, and immersion temperatures as sub-subplots. One ANOVA was performed on indices obtained on the five dates when differences in soil matric potentials existed between the two treatments, and a second analysis was performed on indices obtained on dates when soil matric potentials of the two treatments were equal.

Determinations of plant water potential were made on each of the 10 sampling dates using the pressure bomb. Color and quality ratings, using a scale of 1 to 9 , with $1=$ poor color or quality, were made on the plots on nine dates in 1985. A one tailed $T$ test was used to analyze both color and quality ratings on each rating date. Soil cores were removed from each of the six plots on four sampling dates and rooting depths were measured as previously described. Rooting depths were analyzed using a one tailed $T$ test on each of the four sampling dates.

\section{RESULTS AND DISCUSSION}

\section{Heat Tolerance Monitoring Study}

The heat tolerance indices (HTI) for 1984 showed a general increase from midspring to late spring, with the indices remaining relatively high until late summer when they declined (Fig. 1). A general increase in heat tolerance from spring to summer and decline from summer to fall was not as apparent in 1985 due to the relatively high temperatures at the beginning and end of the sampling period. Heat tolerance indices obtained in 1985 were, in general, considerably higher than those obtained in 1984. The mean maximum temperature for the 2 days prior to sampling was $24.7^{\circ} \mathrm{C}$ in 1984 compared to $27.5^{\circ} \mathrm{C}$ for 1985 . The mean minimum temperature for the 2 days immediately preceding sampling in $1984\left(11.9^{\circ} \mathrm{C}\right)$ was considerably lower than that for $1985\left(15.2^{\circ} \mathrm{C}\right)$.

The highest and lowest HTI were from samplings on 27 June 1985 and 1 June 1984, respectively. Although the lowest HTI occurred in conjunction with the lowest mean maximum temperature (1 June 1984), the greatest HTI (27 June 1985) did not occur in association with the highest mean maximum temperature, which occurred on 10 September 85 .

Correlation coefficients between HTI and the mean maximum air and soil temperatures for the 2 days prior to sampling were 0.79 and 0.73 , respectively. Good correlations were also found between HTI and mean minimum air $(r=0.74)$ and soil temperatures $(r=0.78)$. Total precipitation measured during the period 2 to 4 days prior to sampling, soil matric potential from the morning of and 2 days prior to sampling, and plant water potential measured at the time of heat stress imposition did not correlate with HTI $(r=0.23,-0.05$, and -0.16 , respectively $)$.

The best regression equation fitted to HTI for all sampling dates was $y=15.6 \times A+9.85 \times B-0.22$ $\times A^{2}-0.31 \times B^{2}-0.25 \times A \times B-194.71\left(R^{2}\right.$ $=0.78, p=0.0001$, where $A=$ mean maximum daily air temperature $\left({ }^{\circ} \mathrm{C}\right)$ for the 2 days preceding sampling, and $B=$ mean total precipitation (mm) of the period 2 through 4 days prior to sampling. Even though there was not a significant correlation between HTI and total precipitation, adding total precipitation to the equation increased the $R^{2}$ value of the equation. The mean of the absolute values of the differences occurring between the actual and predicted HTI for the sampling dates was 7.84 index points. Differences of 10 points or more occurred on six sampling dates. Previous research has demonstrated the conditioning effect of the growing temperatures and moisture regime on the heat tolerance of plants (Julander, 1945; Lange, 1965; Levitt, 1980; Wehner and Watschke, 1981; Wehner et al., 1985).

The solution of the prediction equation for the maximum HTI is a mean maximum air temperature of $34.5^{\circ} \mathrm{C}$ and a mean rainfall of $1.9 \mathrm{~mm} \mathrm{day}^{-1}$. At the maximum values, an HTI of 84.0 was obtained; a value below the highest HTI (103.24) obtained from the 27 June 1985 sampling.

The soil matric potential and plant water potential are more direct measures of plant water status than total precipitation, yet the two variables were less useful in predicting heat tolerance than was total precipitation. The soil matric potential measurements taken at the $5-\mathrm{cm}$ depth probably did not consistently indicate the soil moisture conditions to which the plants were exposed, since the depth of the root system was more shallow than the tensiometer cup during the warmest part of the growing season. The rooting depths 
of the annual bluegrass stand on 10 dates in 1985 are shown in Fig. 2. Maximum root depth occurred on 26 April, while the minimum root depth was found on 5 August. The root system showed a decrease in depth from spring into late summer, with an increase in rooting depth occurring in the fall. The correlation coefficient between the maximum soil temperature and rooting depth was -0.83 . During the portion of the growing season when the root system was extremely shallow, plants were observed to wilt on days when the soil matric potential was $0 \mathrm{kPa}$ at the $5-\mathrm{cm}$ depth. Examination of the soil surface revealed that the area where the majority of roots were located was extremely dry.

The surface response curve generated from the prediction equation is shown in Fig. 3 . The range of the predictor variables used in generating the response sur- face was the same as the range occurring in the mean maximum air temperature and mean total precipitation associated with the sampling dates. The response surface suggests an increase in heat tolerance when increasing mean maximum air temperatures are accompanied by decreasing mean total precipitation.

\section{Water Study}

The results of the ANOVA for HTI of annual bluegrass under two moisture regimes for dates when the soil matric potentials were different between treatments (Table 1) and for dates when the soil matric potentials were equal (saturated soil, $0.0 \mathrm{kPa}$ ) are presented in Table 2. The results for each group of dates were similar. Only the immersion temperature and date were significant, evidently because plant injury

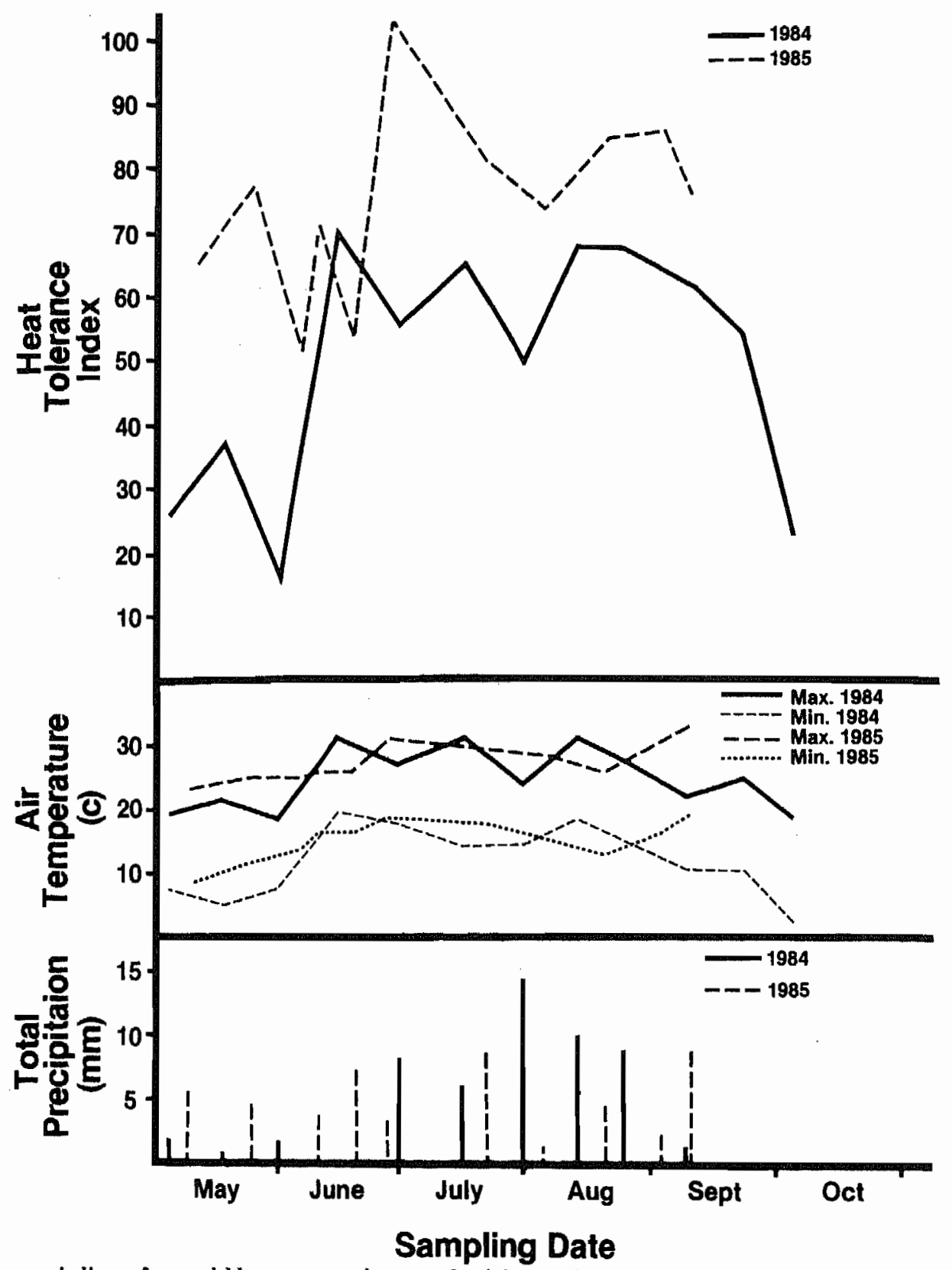

Fig. 1. Heat tolerance indices of annual bluegrass, maximum and minimum air temperature, and total precipitation associated with each sampling date for heat tolerance in 1984 and 1985 . Air temperatures are for the 2-day period prior to sampling. Total precipitation is for the period 2 through 4 days prior to sampling. 
increased as immersion temperature increased and, as seen earlier, HTI was influenced by sampling date environment. The treatment effect for dates when the soil matric potentials were unequal had a probability

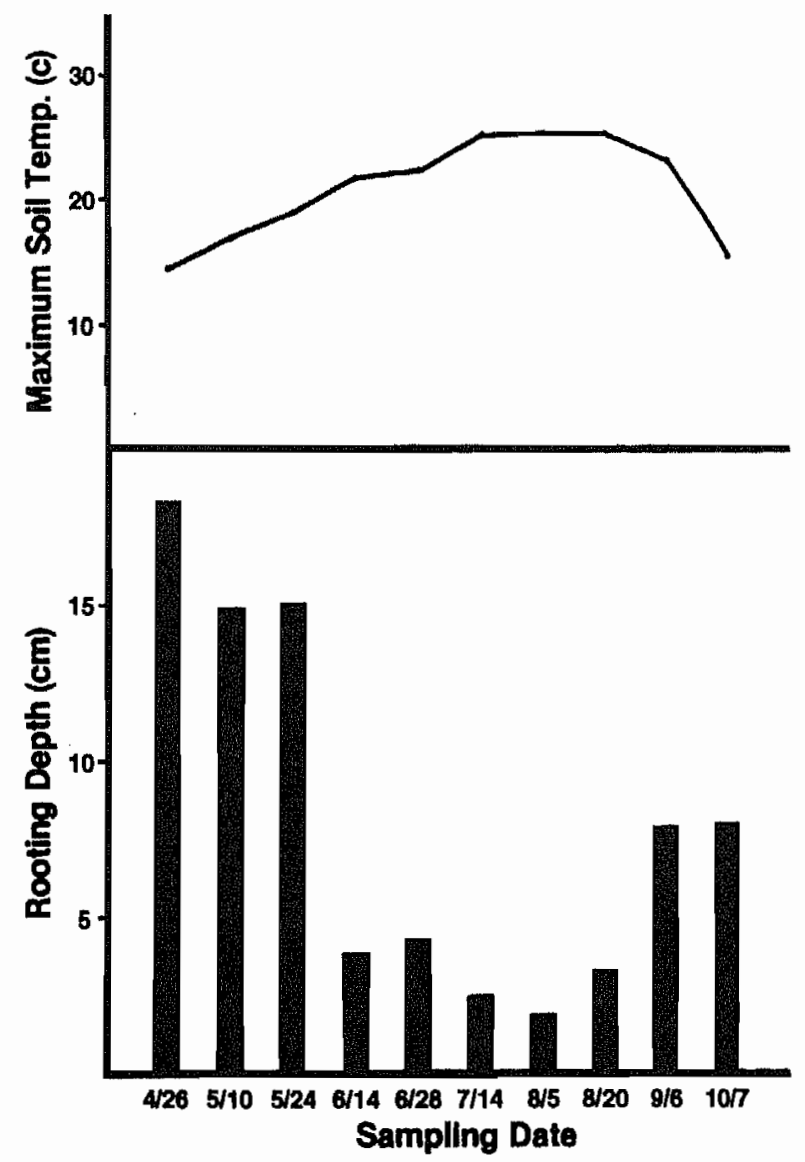

Fig. 2. Maximum soil temperature and rooting depth of annual bluegrass on 10 dates in 1985. for a greater $F=0.11$; the treatment effect for dates when the soil matric potentials were equal had a probability of a greater $F=0.09$. As shown in Fig. 4, the HTI for the wet treatment was lower than the HTI for the dry treatment on nine of the ten sampling dates. The only sampling date when annual bluegrass under the wet treatment was more heat tolerant than that under the dry treatment was on 29 August. The reason for the reversal in the trend of heat tolerance on this sampling date is not known.

The fact that annual bluegrass under the dry treatment was more heat tolerant even when the soil was saturated indicated that the conditioning effect of low moisture was very important. There was poor correlation between HTI for the 10 sampling dates and the soil matric potential measured at the time of sampling

Table 2. Analysis of variance for heat tolerance indices of annual bluegrass treated with two different moisture regimes. Plants sampled for heat tolerance on five dates when soil matric potentials between treatments were equal (saturated soil, $0.0 \mathrm{kPa}$ ) and five dates when soil matric potentials were unequal at the 5-cm depth. Plants were heated at 43,44 , and $45^{\circ} \mathrm{C}$.

\begin{tabular}{|c|c|c|c|c|}
\hline \multirow[b]{3}{*}{ Source } & \multicolumn{4}{|c|}{ Soil matric potentials } \\
\hline & \multicolumn{2}{|c|}{ Equal } & \multicolumn{2}{|c|}{ Unequal } \\
\hline & df & MS & df & MS \\
\hline Replication (R) & 2 & 1195 & 2 & 538 \\
\hline Treatment (Trt) & $i$ & $2533 \dagger$ & 1 & $2542 \dagger$ \\
\hline Trt $\times \mathbf{R}$ & 2 & 271 & 2 & 342 \\
\hline Date (d) & 4 & $3861 * *$ & 4 & $7465^{* * *}$ \\
\hline $\mathrm{D} \times \mathrm{Trt}$ & 4 & 489 & 4 & 256 \\
\hline$D \times \operatorname{Trt} \times \mathbf{R}$ & 16 & 809 & 16 & 520 \\
\hline Temperature (Temp) & 2 & $8108^{* *}$ & 2 & $796 * *$ \\
\hline Temp $\times \mathrm{D}$ & 8 & 290 & 8 & 381 \\
\hline Temp $\times$ Trt & 2 & 82 & 2 & 192 \\
\hline Temp $\times D \times$ Trt & 8 & 165 & 8 & 173 \\
\hline Temp $\times \mathrm{D} \times$ Trt $=\mathrm{R}$ & 40 & 137 & 40 & 265 \\
\hline
\end{tabular}

**, Significant at $p=0.01$. † Significant at $p=0.09$.

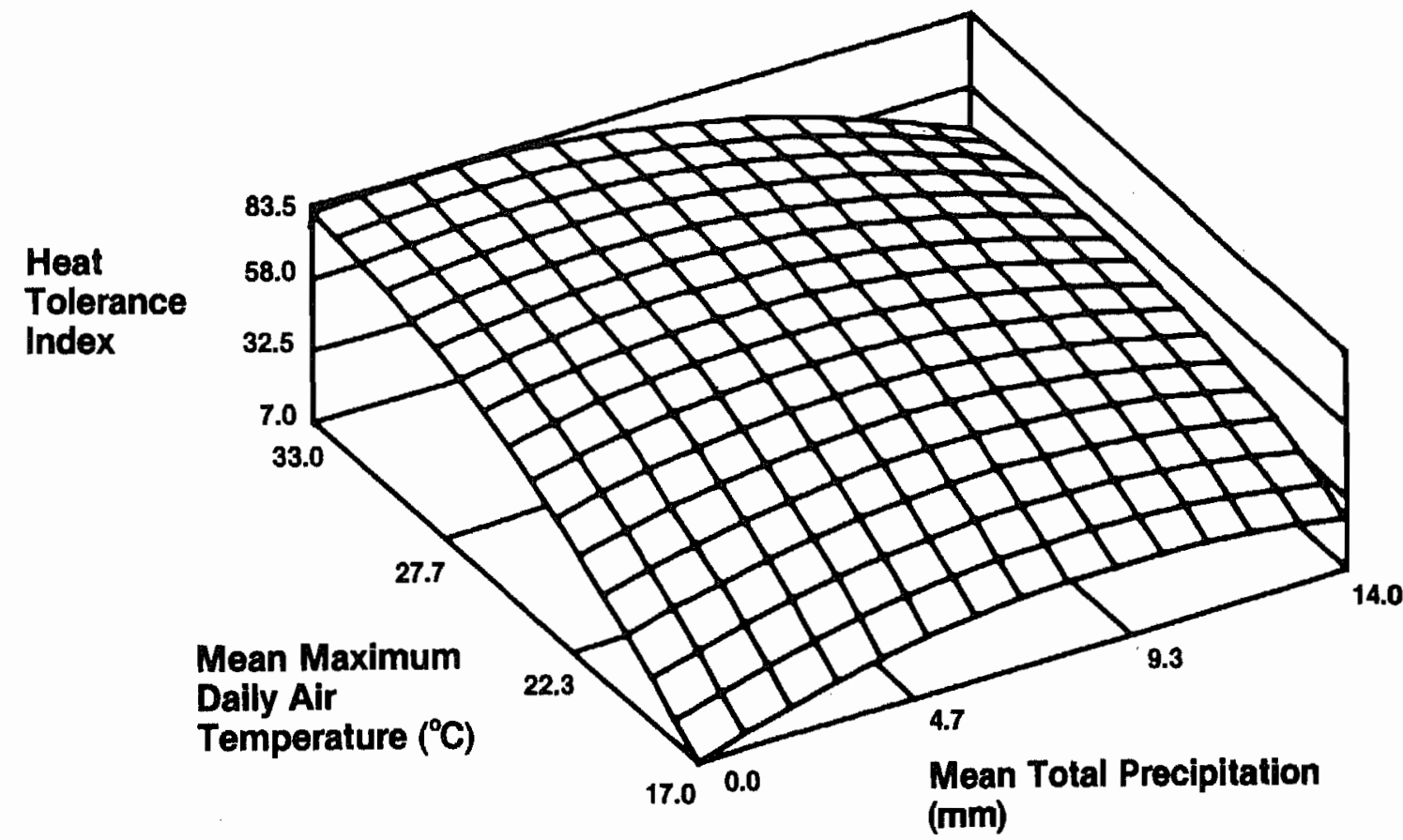

Fig. 3. Response surface generated from the prediction equation $y=15.6 \times A+9.85 \times B-0.22 \times A^{2}-0.31 \times B^{2}-0.25 \times A \times B$ - $194.71\left(R^{2}=0.78, p=0.001\right)$, where $A=$ mean maximum daily air temperature $\left({ }^{\circ} \mathrm{C}\right)$ for the 2 days preceding sampling and $B=$ mean total precipitation $(\mathrm{mm})$ for the period 2 through 4 days prior to sampling. 
$(r=-0.23)$ and the plant water potential measured at the time of heat tolerance evaluation $(r=0.12)$. However, except for the 21 June sampling, the HTI decreased when the soil was brought to saturation. This decrease is illustrated in Fig. 4, where the curves for dates when the soil matric potential was equal are below the curves for the dates when the soil matric potential was unequal. These results indicate the importance of moisture on heat tolerance and the difficulty in deciding which moisture parameter should be monitored.

There was no significant difference due to moisture treatment in annual bluegrass rooting depth on any of the four dates when roots were examined. It is possible that any effects due to moisture treatment on rooting depth were masked by the effect of soil temperature.

Color and quality ratings for annual bluegrass maintained under the two moisture treatments are shown in Fig. 4. The trends in both ratings were similar; the turf receiving the wet treatment received higher color and quality ratings for the majority of the dates. Although the last sampling date for heat tolerance was conducted on 29 August, the two watering treatments continued to be practiced until the 22 September rating date. A color or quality rating of 7 and above was considered satisfactory. The mean color ratings of annual bluegrass maintained under the wet treatment were less than those of the dry treatment on 25 August

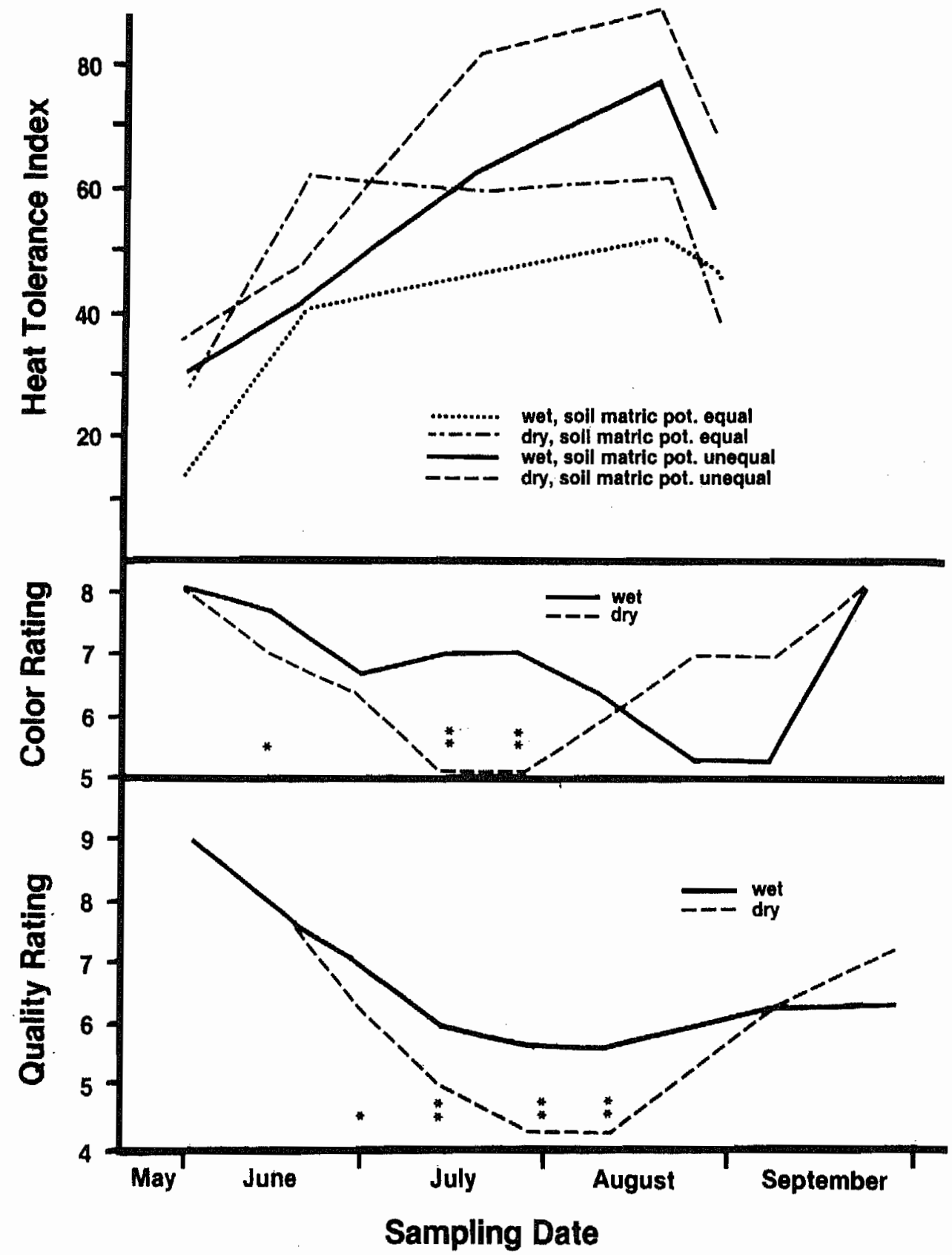

Fig. 4. Heat tolerance indices and color and quality ratings for annual bluegrass maintained under two moisture regimes. Samples were taken on five dates when the soil matric potential was equal and five dates when soil matric potential was different between treatments.* ${ }^{\star \star}$ . Significant difference at $p=0.05$ or 0.01 . 
and 8 September. The possibility exists that the annual bluegrass maintained under the wet treatment was subjected to a $\mathrm{N}$ deficiency later in the growing season when temperatures again became favorable for growth. The large quantities of water applied during the summer in order to maintain the treatment under more positive soil matric potentials may have caused leaching of available $\mathrm{N}$ to a greater extent than occurred under the dry treatment. Also, annual bluegrass under the wet treatment showed greater levels of damage by the fungi (Lanzia and Moellerodiscus spp.) causing dollar spot disease during the later portion of the growing season. Dollar spot disease has been noted to be more severe on susceptible turfgrass species subjected to lower levels of available N (Smiley, 1983).

Although heat tolerance of annual bluegrass is greater under conditions of reduced soil moisture, consideration must be given for the ultimate use of the turf. Reducing the water applied to annual bluegrass caused a reduction in color and quality when use of the turf for golf would be greatest. Reduction in the quantity of water applied to annual bluegrass did not appear to have any effect on depth of the root system. Because of the reduction in turfgrass quality under the dry treatment, there appeared to be little value in increasing heat tolerance through irrigation management. The narrow range in soil matric potentials between the wet treatment where annual bluegrass quality was acceptable and the dry treatment left little room for further gradation in moisture levels.

The results of the water study point out the need for a moisture term in a prediction equation for annual bluegrass heat tolerance. In the monitoring and water studies, there was not good correlation between HTI and soil matric potential, plant water potential, or total precipitation prior to sampling. The best fit prediction equation did, however, utilize total precipitation. Further research is needed to determine what parameter would be best used for the moisture term. Whatever term is used, it must be easily measured by turfgrass managers in the field if the equation or prediction model is to be useful.

\section{REFERENCES}

Boyer, J.S. 1967. Leaf water potentials measured with a pressure chamber. Plant Physiol. 42:133-137.

Calder, D.M. 1973. The effect of temperature on growth and dry weight distribution of populations of Poa annua L. p. 145-152. In R.O. Slatyer (ed.) Plant response to climatic factors. Proc. Uppsala Symp. of UNESCO. Paris, France.

Cordukes, W.E. 1977. Growth habit and heat tolerance of a collection of Poa annua plants. Can. J. Plant Sci. 57:1201-1204.

Duff, D.T. 1978. Disagreement arises over variants of annual bluegrass p. 1-3. In R. Skogley (ed.) Turfgrass Research Review 3(1). University of Rhode Island Cooperative Extension Service, Kingston.

Julander, 0.1945 . Drought resistance in range and pasture grasses. Plant Physiol. 20:573-579.

Lange, O.L. 1965. The heat resistance of plants, its determination and variability. p. 395-405. In F. Eckhardt (ed.) Methodology of plant eco-physiology. Proc. Montpellier Symp. of UNESCO. Paris, France.

Levitt, J. 1980. Responses of plants to environmental stresses. Vol. I. Chilling, freezing, and high temperature stresses. Academic Press, New York.

Martin, D.L. 1986. Studies on annual bluegrass (Poa annua L.) heat tolerance. M.S. thesis. Univ. of Illinois, Urbana.

Minner, D.D., P.H. Dernoeden, D.J. Wehner, and M.S. McIntosh. 1983. Heat tolerance of field-grown cultivars of Kentucky bluegrass and perennial ryegrass. Agron. J. 75:772-775.

SAS Institute, Inc. 1982. SAS user's guide: Statistics. Statistical Analysis Systems Institute, Cary, NC.

Smiley, R. 1983. Compendium of turfgrass diseases. Disease Compendia Series. American Phytopathological Society, St. Paul, MN.

Wallner, S.J., M.R. Becwar, and J.D. Butler. 1982. Measurement of turfgrass heat tolerance in vitro. J. Am. Soc. Hort. Sci. 107:608613.

Wehner, D.J., D.D. Minner, P.H. Dernoeden, and M.S. McIntosh. 1985. Heat tolerance of Kentucky bluegrass as influenced by preand post-stress environment. Agron. J. 77:376-378.

-_-, and T.L. Watschke. 1981. Heat tolerance of Kentucky bluegrasses, perennial ryegrasses, and annual bluegrass, Agron. J. 73:7984. 